[Review Paper]

\title{
Platinum-loaded Sulfated Zirconia Catalyst for Isomerization of Light Naphtha
}

\author{
Takao KIMURA $^{\dagger 1) *}$, Toshio SHIMIZU ${ }^{\dagger 1)}$, and Tetsuya IMAI ${ }^{\dagger 2}$ \\ †1) Research and Development Center, Cosmo Oil Co., Ltd., 1134-2 Gongendo, Satte, Saitama 340-0193, JAPAN \\ †2) Hiroshima Research and Development Center, Mitsubishi Heavy Industries, Ltd., 4-6-22 Kan-on-shin-machi, \\ Nishi-ku, Hiroshima 733-8553, JAPAN
}

(Received November 26, 2003)

\begin{abstract}
Stabilization of $\mathrm{SO}_{4}{ }^{2-} / \mathrm{ZrO}_{2}$ catalyst activity was investigated using $\mathrm{Pt} / \mathrm{SO}_{4}{ }^{2-} / \mathrm{ZrO}_{2}$ catalyst loaded with a small amount of platinum. Pt-loaded $\mathrm{SO}_{4}{ }^{2-} / \mathrm{ZrO}_{2}$ catalyst showed excellent stability. Presumably the $\mathrm{Pt}$ acted as a promoter for removing coke precursors from the catalyst. The developed $\mathrm{Pt} / \mathrm{SO}_{4}{ }^{2-} / \mathrm{ZrO}_{2}$ catalyst had higher activity than zeolitic catalyst, and higher tolerance to both water and sulfur in feed oil than chlorided alumina catalyst. Commercial operation with the developed catalyst achieved 3 points higher research octane number (RON) of product oil at lower reaction temperature compared with the previous zeolite catalyst used for naphtha isomerization.
\end{abstract}

\section{Keywords}

Sulfated zirconia catalyst, Platinum catalyst, Isomerization, Bifunctional mechanism,

Research octane number, Light naphtha

\section{1. 緒言}

近年，周期律表 3 族または 4 族酸化物に硫酸根を結合させた 硫酸根金属酸化物触媒が新しい固体酸触媒として注目され，こ れまでに数多くの研究報告がなされてきている。最初に公表さ れたのは，1962 年の Holm と Baileyによる白金を含む硫酸根 ジルコニアが, 従来の Pt/塩化アルミナに比較してブタン異性 化で優れた触媒活性を示すことを発見した米国特許1)である。 しかし,この触媒は固体酸触媒としての可能性を示したものの, 十分な検討がなされておらず安定した固体酸触媒ではなかっ た。この触媒系の最初の研究報告は, 1979 年に日野, 荒田等 がジルコニア，チタニアおよび鉄酸化物の硫酸，または硫酸ア ンモニウム処理触媒が非常に強い酸性を示し, かつその強酸性 ゆえにブタン異性化を室温で行うことが可能であるとする報告 である ${ }^{2,3)}$ 。この報告では, 超強酸に匹敵する固体酸触媒とし ての性能とその調製方法等についての検討がなされ，新しい固 体酸触媒としての位置付けが明示されている。しかし, 硫酸根 ジルコニア触媒では異性化等の反応に用いた時に瞬時に失活す るため, 工業プロセスでの利用には大きな問題があり解決され ないままであった。

こうした中, 1983 年にコスモ石油(株) と三菱重工業(株)と

\footnotetext{
* To whom correspondence should be addressed.

* E-mail: takao_kimura@cosmo-oil.co.jp

* (Present) International Cooperation Center, Cosmo Oil Co., Ltd., Shibaura Square Bldg., 9-25 Shibaura 4-chome, Minato-ku, Tokyo 180-8564, JAPAN
}

の共同研究 (当時は大協石油(株), アジア石油 (株) および三菱 重工業(株)）により，この触媒失活を克服した極めて安定的な パラフィン異性化能を持つ白金担持硫酸処理ジルコニア触媒が 開発された。この触媒では新しい調製方法と触媒組成の最適化 が十分になされていたため, 上記 Holm 等が示した触媒組成と 類似していたにもかかわらず大幅に改善された触媒性能を示し た4) 7)。その後の商業運転での成功の結果，これまでライトナ フサ異性化触媒として工業的に用いられていた白金/塩素化ア ルミナ触媒抢よび白金/ゼオライト触媒とは異なる異性化性能 を持つ触媒であることが判明した。開発した触媒の特徴は，白 金/塩素化アルミナ触媒に比べ有機塩素化合物を添加する必要 がなく, 原料の厳重な脱水前処理装置が不要なことである。ま た, 白金/ゼオライト触媒よりも低い反応温度で, 高い生成油

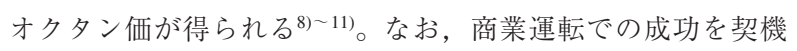
にこれまで世界6 カ国以上で使われるまでに至っている。

本稿は, 1983 年からの旧軽質留分新用途開発技術研究組合 (RAULO) での研究結果を中心に, 金属担持硫酸処理ジルコニ ア触媒の調製方法, 反応特性, 触媒活性発現機構の解明および 商業プロセスの概要等についてまとめたものである。

\section{2. 実験方 法}

\section{1. 原料油の調製}

本実験の原料油は, ペンタン $\left(n-\mathrm{C}_{5}\right)$ および水素化脱硫ライ トナフサ（UFT-LN）を使用した。 $n$ - $\mathrm{C}_{5}$ は国産化学会社製特級 品を用いた。また，UFT-LN は製油所から調達した水添脱硫ラ イトナフサの重質留分を一部カットして事前に処理した後使用 


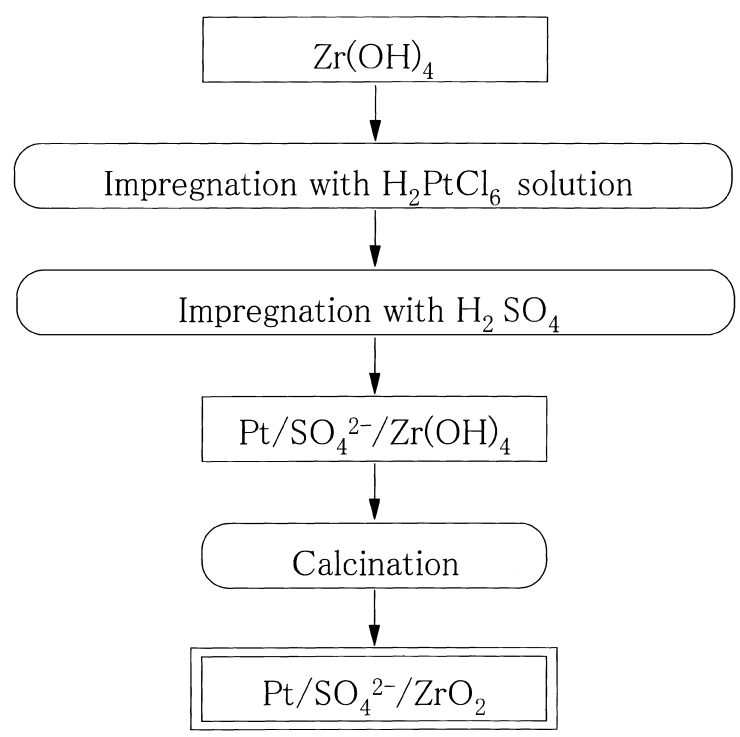

Fig. 1 Preparation of $\mathrm{Pt} / \mathrm{SO}_{4}{ }^{2-} / \mathrm{ZrO}_{2}$ Catalyst

した。原料油中の水分除去は，シリカゲル等の吸着剤により脱 水後実験装置の原料油タンクに充填して, 事前に処理した後に 使用した。また，原料油供給ラインに吸着剤を入れたフィル夕 一を設置してさらに水分を除去した。硫黄添加ナフサ原料油は 脱硫ナフサにジメチルジスルフィド（DMDS）を添加して調製 した。

\section{2. 金属担持硫酸処理ジルコニア触媒の調製}

$\mathrm{Pt} / \mathrm{SO}_{4}{ }^{2-} / \mathrm{ZrO}_{2}$ 触媒を例に調製手順を Fig. 1 に示す。

（1）水酸化ジルコニウムの調製

市販のオキシ塩化ジルコニウム $\left(\mathrm{ZrOCl}_{2} \cdot 8 \mathrm{H}_{2} \mathrm{O}\right)$ を用いて, その水溶液を調製した後, $\mathrm{pH}$ が 9 前後になるようにアンモニ ア水を添加して水酸化ジルコニウム $\left(\mathrm{Zr}(\mathrm{OH})_{x}\right)$ の白色沈殿物 を得る。得られた水酸化ジルコニウム沈殿物を塩素イオンが検 出されなくなるまで水洗後, $110^{\circ} \mathrm{C} に て 12 \mathrm{~h}$ 乾燥して水酸化ジ ルコニウムを得た。

(2) 金属担持

上述の水酸化ジルコニウムに, 塩化白金酸 $\left(\mathrm{H}_{2} \mathrm{PtCl}_{6} \cdot 6 \mathrm{H}_{2} \mathrm{O}\right)$ 水溶液を所定量加え, 真空乾固法により水酸化ジルコニウムに 含浸担持する。その後, $110^{\circ} \mathrm{C} に て 12 \mathrm{~h}$ 乾燥して白金担持水酸 化ジルコニウムを得た。他の貴金属の担持では，塩化パラジウ ム, 塩化ロジウム, 塩化ルテニウム, 硝酸ニッケル，塩化鉄 (III)，パラータングステン酸アンモニウム，モリブデン酸アン モニウムの各水溶液を用いて同様な方法で得た。なお，金属担 持量は $\mathrm{Pt}, \mathrm{Pd}, \mathrm{Rh}$ および Ruについては 0.5 mass\% で，その 他の金属は 5 mass\% である。

(3) 硫酸根処理

$1 \mathrm{~N}$-硫酸水溶液中に, 上記の白金担持水酸化ジルコニウムを 加え (硫酸水溶液: 水酸化ジルコニウム重量比 $=10: 1$ 程度), 室温にて 30 分程度かくはんする。硫酸水溶液をろ過後, $110^{\circ} \mathrm{C}$ にて $12 \mathrm{~h}$ 乾燥して白金担持硫酸処理水酸化ジルコニウムを得 た。他の硫酸根処理方法で, 硫酸アンモニウム処理については 硫酸処理と同様な方法で，また塩化スルフリル処理については
適当量の塩化スルフリル試薬に直接試料を浸した後, 室温で塩 化スルフリルを気化させ, 次いで上記と同様な条件で乾燥させ ることにより得た。

なお，金属担持と硫酸根処理との順序を变えても触媒活性抒 よび物性には影響しなかった。

\section{（4）触媒の焼成}

触媒試料粉末を成型・粉砕にて 16〜28メッシュの粒径に揃 えた後，標準的にはマッフル炉にて $600^{\circ} \mathrm{C}, 3 \mathrm{~h}$ で焼成した。

\section{3. 触媒分析およびキャラクタリゼーション}

(1) 化学分析

触媒の $\mathrm{SO}_{4}{ }^{2-}$ 量は, LECO 装置による高温燃焼赤外吸収法で 測定した。反応後の使用済み触媒のコーク量は, 触媒をへキサ ンでソックスレー抽出処理後に, 乾燥した試料を CHN コーダ 一装置にて測定した。

(2) 物性測定

表面積は，日本べル(株)製表面積測定装置を使用して，窒素 吸着による BET 法により測定した。 $\mathrm{NH}_{3}$-TPD（temperature programmed desorption）および $\mathrm{H}_{2}$-TPD 測定は，自家製の TPD 装置により還元温度 $500^{\circ} \mathrm{C}, 1 \mathrm{~h}$ の触媒前処理を行った後，ア ンモニアガスおよび水素ガスを用いて吸着温度 $100^{\circ} \mathrm{C}, 10^{\circ} \mathrm{C} /$ $\min$ にて昇温して温度 $100 \sim 800^{\circ} \mathrm{C}$ の範囲で行った。触媒の結 晶測定は理学電機(株) 製 X 線回析法装置を用いた。

\section{4. 反応活性試験}

反応実験装置はマイクロリアクターおよびベンチプラントを 用いた。両装置とも下流式固定床流通式反応装置で, 反応器の 形状はそれぞれ内径 $10 \mathrm{~mm} \phi$, 長さ $450 \mathrm{~mm}$ および内径 15.6 $\mathrm{mm} \phi$, 長さ $1200 \mathrm{~mm}$ のステンレス製反応管で, 中心部に熱電 対保護管を装備したものである。反応管中心付近に目皿とガラ スウールによる支持床上に触媒を充填し, その上に予熱部とし て石英砂を管上部まで充填して触媒層を固定した。触媒量は, マイクロリアクターで $2.5 \mathrm{~m} l$, ベンチプラントで $50 \mathrm{ml}$ 程度用 いた。生成物試料は, 反応条件の安定後 $3 \mathrm{~h}$ 程度の予備通油を 実施した後に, マイクロリアクター実験については反応器から 出てきた全生成物を自動サンプリング装置により，またベンチ プラント実験では反応器から出てきた生成物をセパレーターで 分離してガス拉よび生成油を採取し, 各々をガスクロマトグラ フィー $(\mathrm{GC})$ で分析した。

触媒活性の評価は以下のようなペンタンの異性化率を用いた。

$\mathrm{C}_{5}$ 異性化率 $(\%)=i-\mathrm{C}_{5} /$ 全 $\mathrm{C}_{5}$

転化率 $(\operatorname{mass} \%)=100$ 一未反応原料（mass\%)

また, 異性化反応速度定数は, Voorhies 等の方法により算出 した ${ }^{12)}$ 。重水素雲囲気下に扔けるペンタンの固定床流通式反応 による生成物の重水素化率の測定は HP 製 GC-MS（gas chromatography mass spectroscopy）装置を用いて行い, ペンタンの 重水素化数 $0 \sim 12$ の各分子イオンについて, Selected イオンク ロマトグラフで得られるピーク強度を面積比で相対比較するこ とにより重水素化率を算出した。

原料油中の水分量はカールフィッシャー電量滴定法で測定し た。また, 生成油のリサーチ法オクタン価（RON）は, GC 分 析で得られた各成分の重量収率にその固有の RON を乗じて積 算した。 


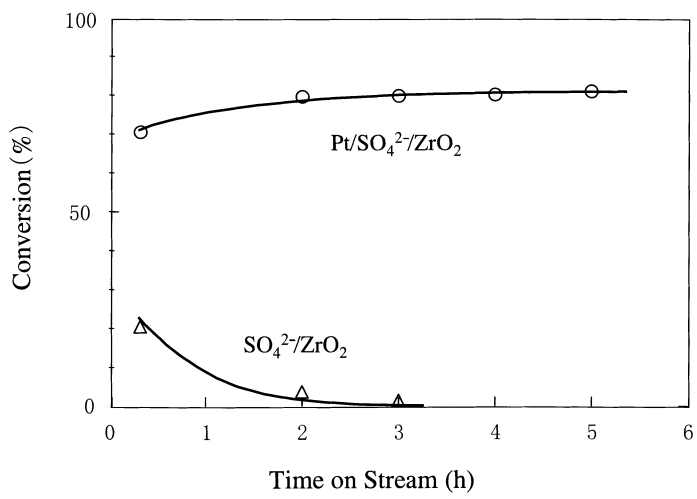

Feed oil: $n-\mathrm{C}_{5} . \quad$ Temp. $=140^{\circ} \mathrm{C}$, Press. $=2 \mathrm{MPa}, \mathrm{LHSV}=1.5$ $\mathrm{h}^{-1}, \mathrm{H}_{2} / n-\mathrm{C}_{5}=1.5 \mathrm{~mol} / \mathrm{mol}$.

Fig. 2 Effect of Pt Addition on the Activity of $\mathrm{SO}_{4}{ }^{2-} / \mathrm{ZrO}_{2}$ Catalyst

\section{3. 結果および考察}

\section{1. 硫酸処理ジルコニア触媒の Pt 担持による異性化活性 の安定化}

$\mathrm{SO}_{4}{ }^{2-} / \mathrm{ZrO}_{2}$ 触媒に 0.5 mass\% $\mathrm{Pt}$ を担持すると, ペンタンの異 性化における触媒活性掞よび安定性が著しく向上する効果を見 い出した。Fig. 2 に示すように, $\mathrm{SO}_{4}{ }^{2-} / \mathrm{ZrO}_{2}$ 触媒では反応初期 に活性は見られるものの, 数時間程度で完全に失活するのに対 して, Pt を担持した触媒では全く活性劣化が起こっていない 結果が得られた。 $\mathrm{Pt} / \mathrm{SO}_{4}{ }^{2-} / \mathrm{ZrO}_{2}$ 触媒は $140^{\circ} \mathrm{C}$ 程度からパラフィ ンの異性化が進むことから, 工業プロセスで用いられているゼ オライト触媒よりも大幅に反応温度が低く, 塩素化アルミナ系 触媒よりもやや高い反応温度特性を持つことが分かった。ガソ リン基材の一つであるライトナフサのオクタン価は, 主成分で あるペンタンとへキサンのイソ体が多いほど高くなり，生成油 は熱平衡に近い組成で得られることから，イソ体に有利な低反 応温度が好ましい。

この $\mathrm{SO}_{4}{ }^{2-} / \mathrm{ZrO}_{2}$ 触媒への $\mathrm{Pt}$ 担持効果は, Fig. 3 に示すよう に 0.5 mass\% まで Pt 担持量が増加するにつれ異性化活性が 徐々に増加し, これに対応して触媒上に生成するコーク量が減 少する結果が示されている。触媒上の $\mathrm{Pt}$ の役割については, $\mathrm{SO}_{4}{ }^{2-} / \mathrm{ZrO}_{2}$ 触媒の固体酸点上で並発するコーク生成抑制に寄与 するものと考えられる。すなわち, 固体酸点上で生成したコー ク前駆体を Pt の水素化能により固体酸点からこれを脱離促進 することであり，この効果は Pt 以外の 8〜10 族金属でも同様 に見られる。Pt，Pd，Rh，Ruをそれぞれ 0.5 mass％，また Ni， $\mathrm{Fe}, \mathrm{Mo}, \mathrm{W}$ をそれぞれ 5 mass \% 担持した硫酸ジルコニア触媒 の反応結果を Fig. 4 に示すが，この中では Pt が最も高活性を 示した。

\section{2. $\mathrm{Pt} / \mathrm{SO}_{4}{ }^{2-} / \mathrm{ZrO}_{2}$ 触媒の調製条件と固体酸発現}

\subsection{1. 焼成温度の影響}

$\mathrm{Pt} / \mathrm{SO}_{4}{ }^{2-} / \mathrm{ZrO}_{2}$ 触媒調製時に扔ける燒成温度とペンタン異性化 反応速度定数との関係を Fig. 5 に示す。この図から， $600^{\circ} \mathrm{C}$ ま では焼成温度の上昇に伴い触媒活性は急増し， $700^{\circ} \mathrm{C}$ ではほほ $600^{\circ} \mathrm{C}$ 焼成品と同等レベルの活性を示した。しかし， $800^{\circ} \mathrm{C}$ の

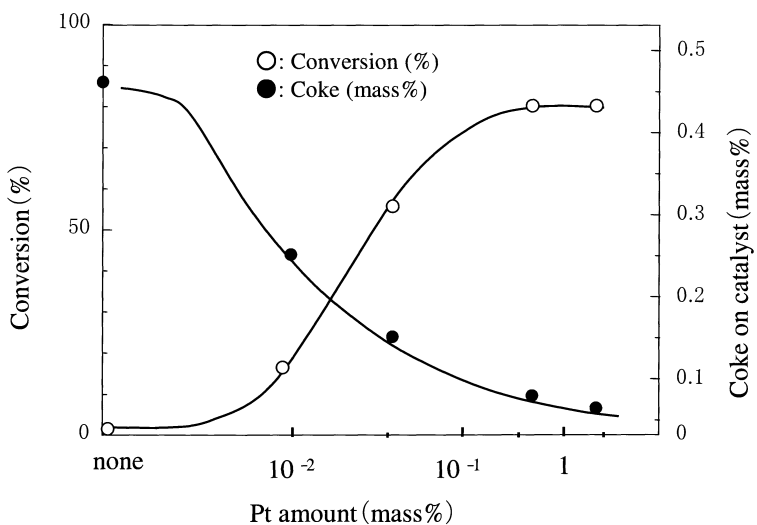

Catalyst: $\mathrm{Pt} / \mathrm{SO}_{4}{ }^{2-} / \mathrm{ZrO}_{2}$. Feed oil: $n-\mathrm{C}_{5} . \quad$ Temp. $=140^{\circ} \mathrm{C}$, Press. $=$ $2 \mathrm{MPa}$, LHSV $=1.5 \mathrm{~h}^{-1}, \mathrm{H}_{2} / n-\mathrm{C}_{5}=1.5 \mathrm{~mol} / \mathrm{mol}$.

Fig. 3 Effect of Pt-loaded $\mathrm{SO}_{4}{ }^{2-} / \mathrm{ZrO}_{2}$ Catalyst on Coke Formation

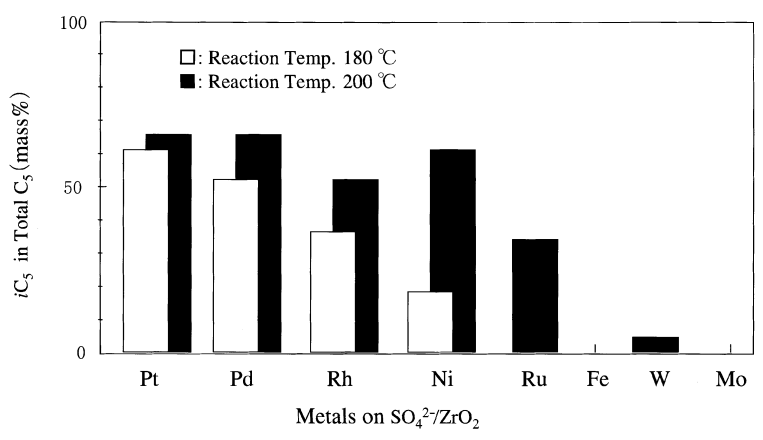

Amount of metals: 0.5 mass \% for Pt, Pd, Rh, Ru and 5 mass \% for the others. Feed oil: $n-C_{5}$. Press. $=1 \mathrm{MPa}, \mathrm{LHSV}=1.5 \mathrm{~h}^{-1}$, $\mathrm{H}_{2} / n-\mathrm{C}_{5}=1.5 \mathrm{~mol} / \mathrm{mol}$.

Fig. 4 Comparison of Transition Metal-loaded $\mathrm{SO}_{4}{ }^{2-} / \mathrm{ZrO}_{2}$ Catalyst

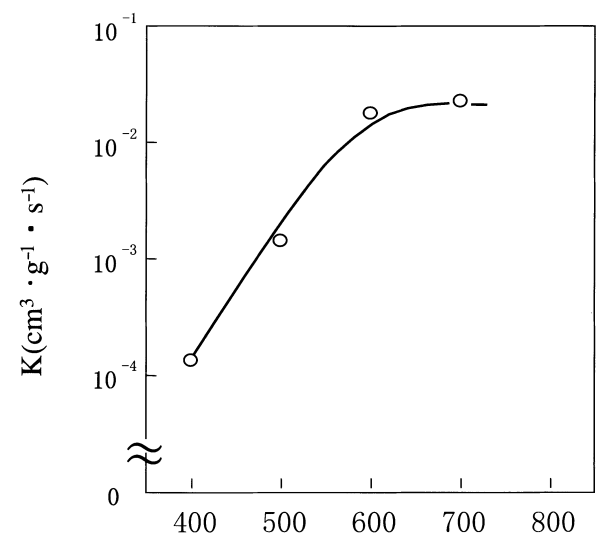

Calcining temperature $\left({ }^{\circ} \mathrm{C}\right)$

Catalyst: $\mathrm{Pt} / \mathrm{SO}_{4}{ }^{2-} / \mathrm{ZrO}_{2}$. Feed oil: $n-\mathrm{C}_{5} . \quad$ Temp. $=200^{\circ} \mathrm{C}$, Press. $=$ $2 \mathrm{MPa}$, LHSV $=1.5 \mathrm{~h}^{-1}, \mathrm{H}_{2} / n-\mathrm{C}_{5}=1.5 \mathrm{~mol} / \mathrm{mol}$

$K$ : kinetic rate decided by Voorhier's method ${ }^{12)}$.

Fig. 5 Effect of Calcining Temperature on the Activity of $\mathrm{Pt} / \mathrm{SO}_{4}{ }^{2-} / \mathrm{ZrO}_{2}$ Catalyst 


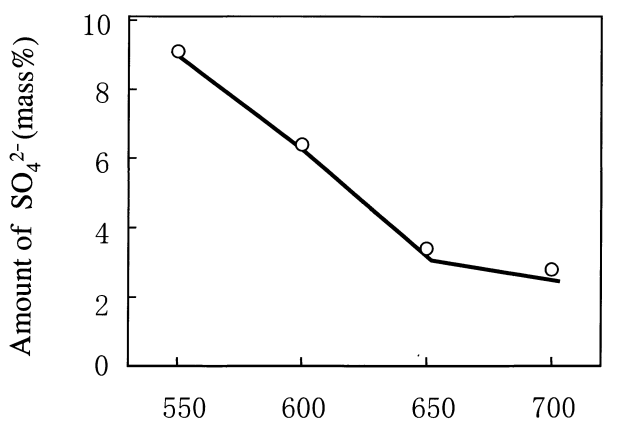

Calcining temperature $\left({ }^{\circ} \mathrm{C}\right)$

Catalyst: $\mathrm{Pt} / \mathrm{SO}_{4}{ }^{2-} / \mathrm{ZrO}_{2}$. Calcining time: $3 \mathrm{~h}$.

Catalyst was treated with $1 \mathrm{~N}$ sulfuric acid solution.

Fig. 6 Correlation between Calcining Temperature and Amount of $\mathrm{SO}_{4}{ }^{2-}$ on $\mathrm{Pt} / \mathrm{SO}_{4}{ }^{2-} / \mathrm{ZrO}_{2}$ Catalyst

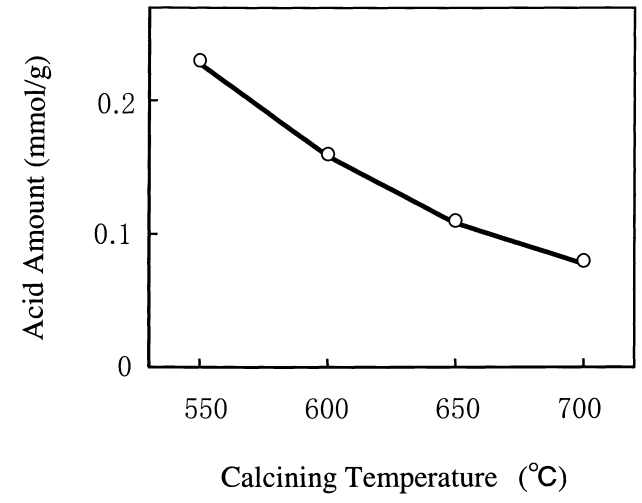

Catalyst: $\mathrm{Pt} / \mathrm{SO}_{4}{ }^{2-} / \mathrm{ZrO}_{2}$. Calcining time: $3 \mathrm{~h}$. Acid amount was measured by $\mathrm{NH}_{3}$-TPD.

Fig. 7 Changes in Amount of Acid with Calcining Temperature of $\mathrm{Pt} / \mathrm{SO}_{4}{ }^{2-} / \mathrm{ZrO}_{2}$ Catalyst

焼成温度では急激に触媒活性が低下した。触媒焼成温度による $\mathrm{SO}_{4}{ }^{2-}$ 量を Fig. 6 に， $\mathrm{NH}_{3}$ - TPD 法で測定される固体酸量および 脱離ピーク温度 $T_{\max }$ の変化を Figs. 7, 8 に示す。触媒の $\mathrm{SO}_{4}{ }^{2-}$ 量は, 焼成温度を上げると $650^{\circ} \mathrm{C}$ までは急激に減少するが, $700^{\circ} \mathrm{C}$ 焼成では $650^{\circ} \mathrm{C}$ よりもわずかに低下した。この時の $\mathrm{NH}_{3}$ 脱離総量で示される酸量は $\mathrm{SO}_{4}{ }^{2-}$ 残存量にほほ比例した傾向を 示すが, $\mathrm{NH}_{3}$ 脱離ピーク温度 $T_{\max }$ で示す酸強度は逆に焼成温 度の上昇とともに $650^{\circ} \mathrm{C}$ まで急激に増加した。これは, ジルコ ニア表面に吸着した硫酸根とジルコニアが直接結合して生成し た強い固体酸のみが残ったためと考えられるが，異性化活性に 必要な酸点は酸強度と酸量とのバランスが重要であると推定し ている。なお，硫酸処理ジルコニア系触媒の焼成温度の影響に

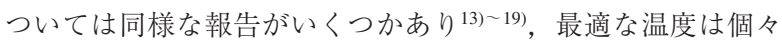
の触媒組成や調製方法で異なるものの, 本触媒系では概ね $550 \sim 650^{\circ} \mathrm{C}$ の範囲である。

\section{2.2. 各種硫酸根処理剤の影響}

硫酸根処理剂として, 硫酸, 硫酸アンモニウムおよび塩化久

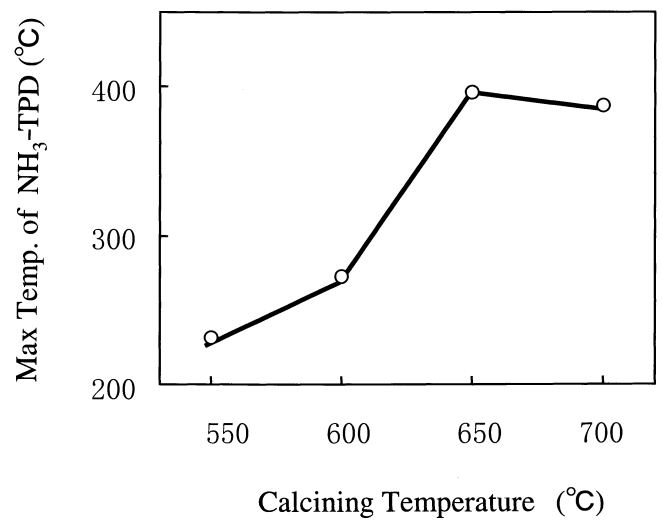

Catalyst: $\mathrm{Pt} / \mathrm{SO}_{4}{ }^{2-} / \mathrm{ZrO}_{2}$. Calcining time: $3 \mathrm{~h}$.

Maximum temperature was measured by $\mathrm{NH}_{3}$-TPD.

Fig. 8 Effect of Calcining Temperature on Acid Strength of $\mathrm{Pt} / \mathrm{SO}_{4}{ }^{2-} / \mathrm{ZrO}_{2}$ Catalyst

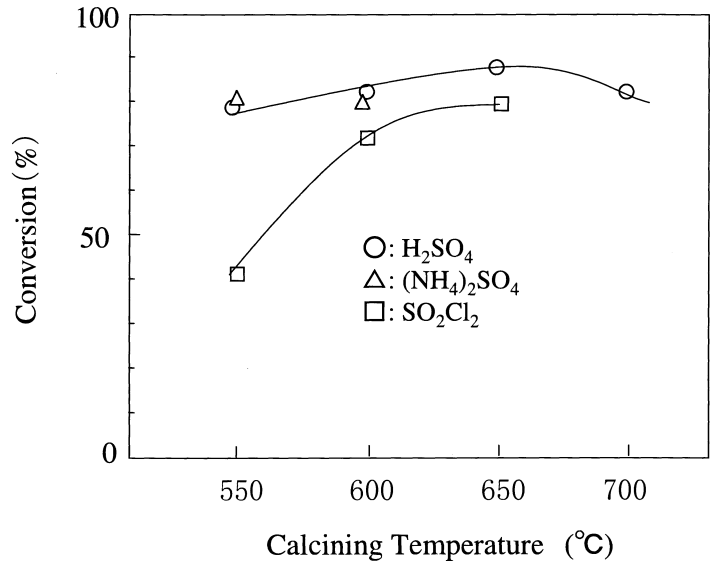

Catalyst: $\mathrm{Pt} / \mathrm{SO}_{4}{ }^{2-} / \mathrm{ZrO}_{2}$. Calcining time: $3 \mathrm{~h}$. Feed oil: $n-\mathrm{C}_{5}$. Temp. $=180^{\circ} \mathrm{C}$, Press. $=2 \mathrm{MPa}, \mathrm{LHSV}=1.5 \mathrm{~h}^{-1}, \mathrm{H}_{2} / n-\mathrm{C}_{5}=1.5$ $\mathrm{mol} / \mathrm{mol}$.

Fig. 9 Comparison of Sulfur Compounds on $\mathrm{Pt} / \mathrm{SO}_{4}{ }^{2-} / \mathrm{ZrO}_{2}$ Catalyst

ルフリルの 3 種類についてその効果を比較検討した。Fig. 9 に, 各々の処理触媒の焼成温度とペンタン異性化活性との相関 を示す。いずれの触媒も焼成温度の上昇に伴って活性が増加し ており, 硫酸アンモニウムと硫酸処理では $550^{\circ} \mathrm{C}$ の焼成温度で ほぼ十分な活性発現が見られている。Fig. 10 に, 各触媒の表 面積あたりの $\mathrm{SO}_{4}{ }^{2-}$ 量について示すが, 塩化スルフリル処理触 媒では全焼成温度領域で触媒表面に過剩の $\mathrm{SO}_{4}{ }^{2-}$ 量が残存して おり, 特に $550^{\circ} \mathrm{C}$ の低温度における焼成条件では顕著であるこ とが分かる。これらの結果から, Fig. 9で示した塩化スルフリ ル触媒活性が低い原因は, 過剩の塩化スルフリルが焼成後でも 触媒中に残存して活性点を被覆したためと考えている。すなわ ち, この硫酸根処理剤の効果の違いは, 硫酸アンモニウムおよ び硫酸では直接強酸点を形成するのに対して, 塩化スルフリル では白金担持水酸化ジルコニウム中の水分，または水酸基との 
加水分解による逐次的形成によるものと推定している。なお， 硫酸を用いた白金担持水酸化ジルコニウムの処理では， $1 \mathrm{~N}$ 程 度の硫酸が適当であることが報告されている20)。

\section{2.3. 硫酸根処理ジルコニア触媒の結晶形態}

熱分析抢よびXRD（X-ray diffraction）の結果から，触媒組 成中のジルコニアは焼成時に結晶転移を起こすことが分かっ た。硫酸根処理していない水酸化ジルコニウムおよび Pt 担持 の水酸化ジルコニウムでは, それぞれ $432^{\circ} \mathrm{C}$ および $452^{\circ} \mathrm{C}$ でア モルファスから単斜晶系 (Monoclinic) へのジルコニア結晶転 移を示す発熱ピークが観察され，この時の重量変化はほとんど 見られなかった。これに対して, 硫酸根処理した水酸化ジルコ ニウムでは重量減少を伴う結晶転移が高温側で観察され，その ジルコニア結晶は正方晶系（Tetragonal）であった。なお，硫 酸根処理水酸化ジルコニウムの $650^{\circ} \mathrm{C}$ 焼成試料は正方晶系構造 を示し, XPS（X-ray photoelectron spectroscopy）スペクトルか ら得られた表面化学種は $\mathrm{ZrO}_{2}$ と $\mathrm{SO}_{4}$ とであることが報告され ている ${ }^{21)}$

これらの結果から, 硫酸根が焼成時のジルコニウムの結晶形 態に影響を与えていることが推察される。Table 1 に, 硫酸根 処理した各種触媒の結晶転移温度, $600^{\circ} \mathrm{C}$ 焼成温度に扔けるジ ルコニアの結晶系およびペンタン異性化触媒としての最適焼成 温度を示す。異性化活性が高かった触媒は結果的に正方晶系の ジルコニア結晶系構造を有していたことが分かる。

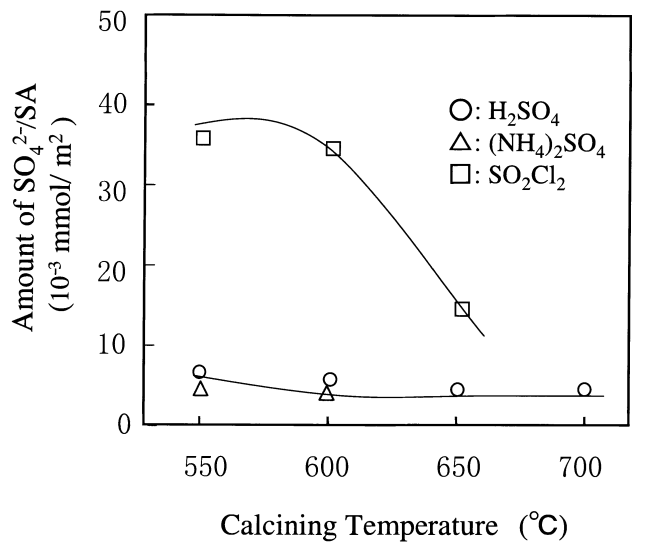

Catalyst: $\mathrm{Pt} / \mathrm{SO}_{4}{ }^{2-} / \mathrm{ZrO}_{2}$. Calcining time: $3 \mathrm{~h}$.

Fig. 10 Relationship between Calcining Temperature and Amount of $\mathrm{SO}_{4}{ }^{2-} /$ S.A. of Catalysts

\section{2. 4. 硫酸根処理ジルコニア触媒の固体酸性質}

上述したように，硫酸根処理ジルコニア触媒の $\mathrm{NH}_{3}$-TPD で 観測される固体酸性は, $600 \sim 700^{\circ} \mathrm{C}$ の焼成で比較的強い酸点 であると考えられるが，別途 Hammett 指示薬法で $\mathrm{pKa} \leqq$ -13.75 に相当する固体酸を有することを確認している5)。

ところで，触媒の固体酸測定にはピリジン吸着 IR（infrared spectroscopy）法も多く使われ， $\mathrm{SO}_{4}{ }^{2-} / \mathrm{ZrO}_{2}$ 系触媒では約 1450 $\mathrm{cm}^{-1}$ と約 $1540 \mathrm{~cm}^{-1}$ とにそれぞれ $\mathrm{L}$ 酸と $\mathrm{B}$ 酸に帰属される 2 種 類の酸点が共存しているという報告が多(21) 23)。ピリジン吸 着 IR 法による $\mathrm{Pt} / \mathrm{SO}_{4}{ }^{2-} / \mathrm{ZrO}_{2}$ 触媒の固体酸を測定した結果で は, 同様な 2 種類の酸点の存在を確認している。しかし, 長期 反応実験の途中で抜き出した触媒について同様な測定を行った 結果，フレッシュ触媒では観察された $\mathrm{L}$ 酸，B 酸は触媒上層 ではどちらも検出されず，中層抢よび下層で L 酸のみが検出 された。これは, 触媒層の上層から下層にかけて徐々に酸点上 で生成たい積するコークが触媒酸点を被覆して行く様子を示し ているものと推定しているが, 本触媒の異性活性に寄与してい る触媒活性点が L 酸か，もしくはIRスペクトルで明暸に示さ れないほどの微量 B 酸のどちらかは不明である。

\section{3. $\mathrm{Pt} / \mathrm{SO}_{4}{ }^{2-} / \mathrm{ZrO}_{2}$ 触媒での白金の役割}

$\mathrm{Pt} / \mathrm{Al}_{2} \mathrm{O}_{3}, \mathrm{Pt} / \mathrm{ZrO}_{2}$ および $\mathrm{Pt} / \mathrm{SO}_{4}{ }^{2-} / \mathrm{ZrO}_{2}$ 各触媒の $\mathrm{H}_{2}-\mathrm{TPD}$ 測定 結果を Table 2 に示す。 $800^{\circ} \mathrm{C}$ までの水素脱離量から計算され る $\mathrm{Pt}$ の水素保持量は, $\mathrm{Pt} / \mathrm{SO}_{4}{ }^{2-} / \mathrm{ZrO}_{2}$ 触媒ではほとんどなく (0.01 水素原子 $/ \mathrm{Pt}$ 原子), 代表的な $\mathrm{Pt}$ 担持系触媒である $\mathrm{Pt} / \mathrm{Al}_{2} \mathrm{O}_{3}$ 触媒 (0.83 水素原子 / $\mathrm{Pt}$ 原子 $)$ と比較すると $\mathrm{Pt}$ 粒子 表面は見かけ上還元されていないように見える。この結果は, $600^{\circ} \mathrm{C}$ 焼成 $\mathrm{Pt} / \mathrm{SO}_{4}{ }^{2-} / \mathrm{ZrO}_{2}$ の触媒が全く水素吸着を示さなかった という報告 ${ }^{24)}$ とほほ一致する。

一方, 各種 Pt 触媒の水素化能について, モデル反応として 行ったエチレンおよびシクロプロパンの水素化反応の結果をそ

Table $2 \mathrm{H}_{2}$ Uptake of $\mathrm{Pt} / \mathrm{SO}_{4}{ }^{2-} / \mathrm{ZrO}_{2}$ Catalyst Measured by TPD $^{\mathrm{a})}$

\begin{tabular}{lccc}
\hline Catalyst & $\begin{array}{c}\mathrm{Pt} \\
{[\text { mass \%] }}\end{array}$ & $\begin{array}{c}\mathrm{H}_{2} \text { amount } \\
{[\mu \mathrm{mol} / \mathrm{g}]}\end{array}$ & $\begin{array}{c}\mathrm{H} / \mathrm{Pt} \\
{[\mathrm{atm} / \mathrm{atm}]}\end{array}$ \\
\hline $\mathrm{Pt} / \mathrm{Al}_{2} \mathrm{O}_{3}$ & 0.89 & 18.9 & 0.83 \\
$\mathrm{Pt} / \mathrm{ZrO}_{2}$ & 0.96 & 2.8 & 0.14 \\
$\mathrm{Pt} / \mathrm{SO}_{4}{ }^{2-} / \mathrm{ZrO}_{2}$ & 0.79 & 0.3 & 0.01 \\
\hline
\end{tabular}

a) TPD condition was as follows.

Pretreatment: Temp. $500^{\circ} \mathrm{C}, 1 \mathrm{~h}$ with $\mathrm{H}_{2}$ flow.

$\mathrm{H}_{2}$ adsortption: Temp. $100^{\circ} \mathrm{C}$.

$\mathrm{H}_{2}$ desorption: Temp. $100-800^{\circ} \mathrm{C}$ by $100^{\circ} \mathrm{C} / \mathrm{min}$.

Table 1 Effect of Calcining Temperature on $\mathrm{ZrO}_{2}$ Based Catalysts Exposed to Various Sulfur Compounds

\begin{tabular}{lccr}
\hline Composition & $\begin{array}{c}\text { Transition temp. } \\
\text { for crystal }\left[{ }^{\circ} \mathrm{C}\right]\end{array}$ & $\begin{array}{c}\text { Crystal phase } \\
\text { calcined at } 600{ }^{\circ} \mathrm{C}\end{array}$ & $\begin{array}{c}\text { Optimum calcining temp. } \\
{\left[n-\mathrm{C}_{5} \text { isomerization, }{ }^{\circ} \mathrm{C}\right]}\end{array}$ \\
\hline $\mathrm{ZrO} 2$ & 432 & Monoclinic & - \\
$\mathrm{Pt} / \mathrm{ZrO}_{2}$ & 452 & Monoclinic & 650 \\
$\mathrm{Pt} / \mathrm{H}_{2} \mathrm{SO}_{4} / \mathrm{ZrO}_{2}$ & 616 & Tetragonal & $550-600$ \\
$\mathrm{Pt} /\left(\mathrm{NH}_{4}\right)_{2} \mathrm{SO}_{4} / \mathrm{ZrO}_{2}$ & 514 & Tetragonal & $650<$ \\
$\mathrm{SO}_{2} \mathrm{Cl}_{2} / \mathrm{ZrO}_{2}$ & 676 & Amorphous & (+ Tetragonal) \\
& & & \\
\hline
\end{tabular}


れぞれ Tables 3 および 4 に示す。 $\mathrm{Pt} / \mathrm{SO}_{4}{ }^{2-} / \mathrm{ZrO}_{2}$ 触媒上の $\mathrm{Pt}$ は, アルミナやジルコニアに担持した Ptに比べて低温での水素化 活性は劣っているものの, $100^{\circ} \mathrm{C}$ 以上では十分な水素化能が保 持されていることが分かった。これらの結果から, $\mathrm{Pt} / \mathrm{SO}_{4}{ }^{2-}$ $1 \mathrm{ZrO}_{2}$ 触媒上の $\mathrm{Pt}$ が還元され難い状態になっているものの，水 素化や水素化分解といった $\mathrm{Pt}^{0}$ 金属が示す触媒性能を有してい ることを示すものであり，同様な結果が報告されている24)。ま た，服部らは同触媒系に扔ける Pt の状態観察と触媒作用につ いて数々の検討を行ってきているが25) 34)，これらの結果から $\mathrm{Pt}$ 粒子は内部の $\mathrm{Pt}^{0}$ 金属を $20 \%$ 程度の $\mathrm{Pt}^{4+}$ 酸化物で覆った構 造であるという結論に至っている33)。他に，Ptの状態について いくつかの報告があるが $\mathrm{Pt}^{0}$ が存在する点では一致してい る $^{35) \sim 41)}$ 。

本実験に打ける $\mathrm{Pt} / \mathrm{SO}_{4}{ }^{2-} / \mathrm{ZrO}_{2}$ 触媒上の $\mathrm{Pt}$ 還元度が低かった のは，これらと同様な理由によるものと考えているが，もう一 つの原因として Pt の硫黄被毒が考えられる。これについては, 水素雲囲気下 $400^{\circ} \mathrm{C}$ 付近の高温で触媒 $\mathrm{SO}_{4}{ }^{2-}$ 根の一部が硫化水 素へ還元することが確認されており5)，同様な検討を行った他 の研究でも $\mathrm{SO}_{4}{ }^{2-}$ 根の減少あるいは $\mathrm{Pt}$ の硫黄被毒が示されてい $ろ^{42) \sim 44)}$ 。

以上，上述した Pt 担持によるコーク低減結果とを合わせる と, 本触媒での Pt の役割は, 気相中の水素分子を触媒上にス ピルオーバーし, 硫酸ジルコニア酸点上でのパラフィンの異性 化過程で生成するコーク前駆体を速やかに水素化脱離させるこ とであると考えている。なお，この Pt を経由したスピルオー バー水素については，プロトンの生成45) やハイドライドイオ ンの供給46)に寄与しているとする報告もあり, 今後の解明が 待たれる所である。

\section{4. $\mathrm{Pt} / \mathrm{SO}_{4}{ }^{2-} / \mathrm{ZrO}_{2}$ 触媒上でのペンタン異性化反応機構}

アルカンの骨格異性化の反応機構はカルベニウムイオンの異

Table 3 Hydrogenation of Ethylene with $\mathrm{Pt} / \mathrm{SO}_{4}{ }^{2-} / \mathrm{ZrO}_{2}$ Catalyst

\begin{tabular}{lcc}
\hline Catalyst & $\begin{array}{c}\text { Reaction temp. } \\
{\left[{ }^{\circ} \mathrm{C}\right]}\end{array}$ & $\begin{array}{c}\text { Conversion } \\
{[\%]}\end{array}$ \\
\hline $\mathrm{Pt} / \mathrm{Al}_{2} \mathrm{O}_{3}$ & 140 & $99.9^{+}$ \\
& 50 & $99.9^{+}$ \\
$\mathrm{Pt} / \mathrm{SO}_{4}{ }^{2-} / \mathrm{ZrO}_{2}$ & 140 & $99.9^{+}$ \\
$\mathrm{SO}_{4}{ }^{2-} / \mathrm{ZrO}_{2}$ & 50 & $99.9^{+}$ \\
& 140 & 4.4 \\
& 200 & 5.7 \\
\hline
\end{tabular}

性化によるものであり ${ }^{47)}$, カルベニウムイオン生成は, 金属に 扔ける脱水素・水素化反応と酸点とによる二元機構か, 酸点の みの一元機構のどちらかで起こる45)。また, ブタンの異性化で は単分子反応と 2 分子反応の二つの反応経路が存在するが, ペ ンタン以上のアルカンでは主に単分子反応で48), 特に Pt を担 持した固体酸触媒系ではほぼ単分子で起こると考えられてい る49)。一方, 工業的なペンタン異性化触媒の一つとして用いら

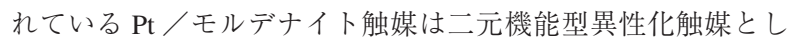
て知られている50)。このことから, 重水素を用いたペンタン異

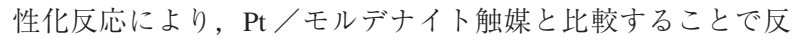
応機構の推定が可能であると考えられる。すなわち, オレフィ ンを経由する二元機能型で異性化反応が進行すると仮定する と, $\mathrm{Pt}$ 上での脱水素㧍よび水素化過程で重水素 D が 2 個交換 された $i-\mathrm{C}_{5}$ の生成割合が最も多くなると考えられる。

Fig. 11 に, $\mathrm{Pt} / \mathrm{SO}_{4}{ }^{2-} / \mathrm{ZrO}_{2}$ 触媒を用いた重水素需囲気下にお けるペンタン異性化反応の結果を, $\mathrm{Pt} /$ モルデナイト触媒と比 較して示す。なお, $\mathrm{Pt} / \mathrm{SO}_{4}{ }^{2-} / \mathrm{ZrO}_{2}$ 触媒では反応温度 $140^{\circ} \mathrm{C}$ およ

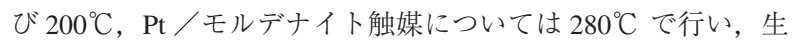
成物中のイソペンタン $\left(i-\mathrm{C}_{5}\right)$ およびペンタン各成分の重水素 置換原子数とその収率を測定した。その結果, $\mathrm{Pt} / \mathrm{SO}_{4}{ }^{2-} / \mathrm{ZrO}_{2}$ 触 媒では反応温度により異なる反応経路を示すことが明らかにな
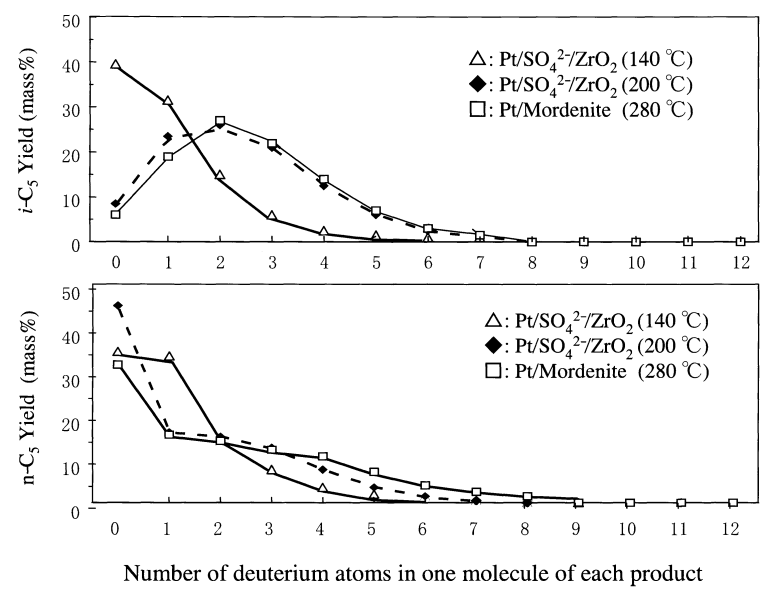

Feed oil: $n-\mathrm{C}_{5} . \quad$ Press. $=1 \mathrm{MPa}, \mathrm{LHSV}=1.5 \mathrm{~h}^{-1}, \mathrm{D}_{2} / n-\mathrm{C}_{5}=1.5$ $\mathrm{mol} / \mathrm{mol}$.

Fig. 11 Distribution of Deuterated Products in Isomerization Reaction of Pentane over Pt/SO ${ }_{4}{ }^{2-} / \mathrm{ZrO}_{2}$ Catalyst

Table 4 Hydrogenation of Cyclopropane with $\mathrm{Pt} / \mathrm{SO}_{4}{ }^{2-} / \mathrm{ZrO}_{2}$ Catalyst

\begin{tabular}{lcccc}
\hline \multirow{2}{*}{ Catalyst } & $\begin{array}{c}\text { Reaction temp. } \\
{\left[{ }^{\circ} \mathrm{C}\right]}\end{array}$ & $\begin{array}{c}\text { Conversion } \\
{[\%]}\end{array}$ & \multicolumn{2}{c}{ Selectivity [\%] } \\
\hline $\mathrm{Pt} / \mathrm{Al}_{2} \mathrm{O}_{3}$ & 70 & 99.5 & 99.9 & 0 \\
$\mathrm{Pt} / \mathrm{ZrO}_{2}$ & 50 & 99.5 & 99.9 & 0 \\
& 70 & 99.9 & 99.8 & 0 \\
$\mathrm{Pt} / \mathrm{SO}_{4}{ }^{2-} / \mathrm{ZrO}_{2}$ & 50 & 99.9 & 99.7 & 0 \\
$\mathrm{SO}_{4}{ }^{2-} / \mathrm{ZrO}_{2}$ & 70 & 93.2 & 99.6 & 0 \\
& 50 & 25.2 & 99.2 & 0 \\
& 100 & 31.6 & 0.7 & 96.6 \\
\end{tabular}




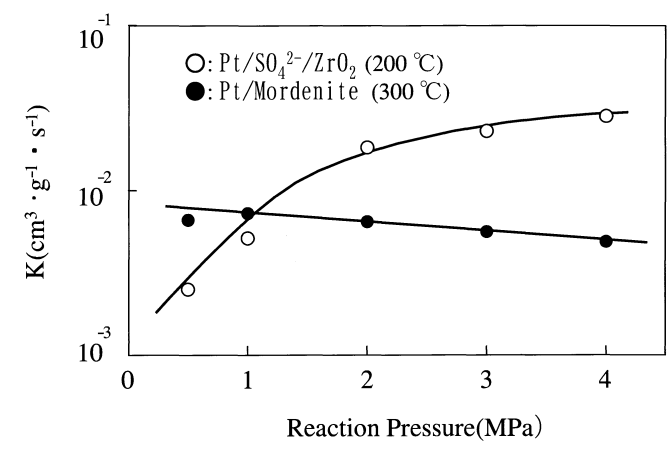

Feed oil: $n-\mathrm{C}_{5} . \quad \mathrm{LHSV}=1.5 \mathrm{~h}^{-1}, \quad \mathrm{H}_{2} / n-\mathrm{C}_{5}=5 \mathrm{~mol} / \mathrm{mol}$. $K$ : kinetic rate decided by Voorhier's method ${ }^{12)}$.

Fig. 12 Effect of Reaction Pressure on the Activity of Pentane Isomerization

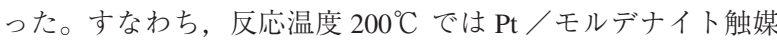
と同様な重水素 2 原子が置換した $i-\mathrm{C}_{5}$ （質量数 74）が最も多 い収率を示したことから，この温度領域では二元機能型反応が 主体となっているものと推定される。一方, 反応温度 $140^{\circ} \mathrm{C}$ で は $\mathrm{D}$ 交換が起こっていない $i-\mathrm{C}_{5}$ （質量数 72）生成割合が多い ことから, 明らかに反応温度 $200^{\circ} \mathrm{C}$ とは異なる結果である。反 応温度 $140^{\circ} \mathrm{C}$ の結果は, 低温反応二元機能型触媒では FriedelCrafts 型と類似した反応機構を経る ${ }^{51)}$ といわれる結果と一致す ると考えている。

次に, $\mathrm{Pt} / \mathrm{SO}_{4}{ }^{2-} / \mathrm{ZrO}_{2}$ 触媒のペンタン異性化に扮ける反応圧力 の影響について, Pt /モルデナイト触媒と比較して Fig. 12 に 示す。同程度の反応速度で比較するため, $\mathrm{Pt} / \mathrm{SO}_{4}{ }^{2-} / \mathrm{ZrO}_{2}$ 触媒は

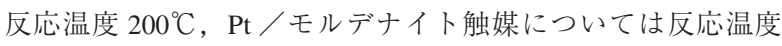

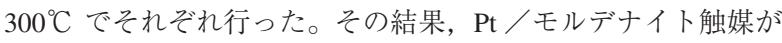
負に近い水素圧力依存性を示すのに対して, $\mathrm{Pt} / \mathrm{SO}_{4}{ }^{2-} / \mathrm{ZrO}_{2}$ 触媒 では大きな正の水素圧力依存性を示した。二元機能型触媒の反 応機構では，触媒金属上で原料アルカンの脱水素によるオレフ イン生成の後, これにプロトンの付加等により生成したカルベ ニウムイオンが酸点上で骨格異性化を起こすと考えられている 50)。この場合, 第一段階の脱水素反応は反応系の水素分圧が低 い方が平衡的に有利であり, 負の水素圧依存性を示すと推定さ れる。 $\mathrm{Pt} / \mathrm{SO}_{4}{ }^{2-} / \mathrm{ZrO}_{2}$ 触媒の正の依存性結果は, 上述したように $200^{\circ} \mathrm{C}$ 反応では二元機能型反応機構が主体であることを示した 結果と一見矛盾しているように見える。しかし， $\mathrm{Pt} / \mathrm{SO}_{4}{ }^{2-} / \mathrm{ZrO}_{2}$ 触媒の二元機能型反応機構に扔いて水素分子の解離が反応律速 であると仮定すると, 前項で示したように本触媒系の Pt の水 素吸着能が低下していることから, 水素分圧の増加により $\mathrm{Pt}$ 上での水素分子解離が高められて反応速度が上昇したものと考 えている。この $\mathrm{Pt} / \mathrm{SO}_{4}{ }^{2-} / \mathrm{ZrO}_{2}$ 触媒による水素特性については 同様な結果が報告されている ${ }^{52)}$-56)。なお，服部らが提案して いる気相の水素分子からスピルオーバーを経てプロトン酸点を 生成するという説 57 では水素圧力依存性の説明が可能である が，詳しいことは不明である。

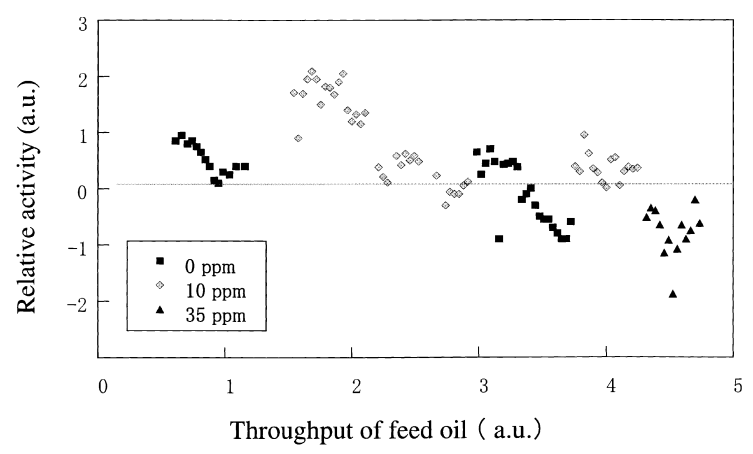

Feed oil: UFT-LN. Temp. $=204^{\circ} \mathrm{C}$, Press. $=1.7 \mathrm{MPa}$, WHSV $=$ $3 \mathrm{~h}^{-1}, \mathrm{H}_{2} / \mathrm{HC}=2 \mathrm{~mol} / \mathrm{mol}$.

Fig. 13 Tolerance of $\mathrm{Pt} / \mathrm{SO}_{4}{ }^{2-} / \mathrm{ZrO}_{2}$ Catalyst to Water in Naphtha Isomerization

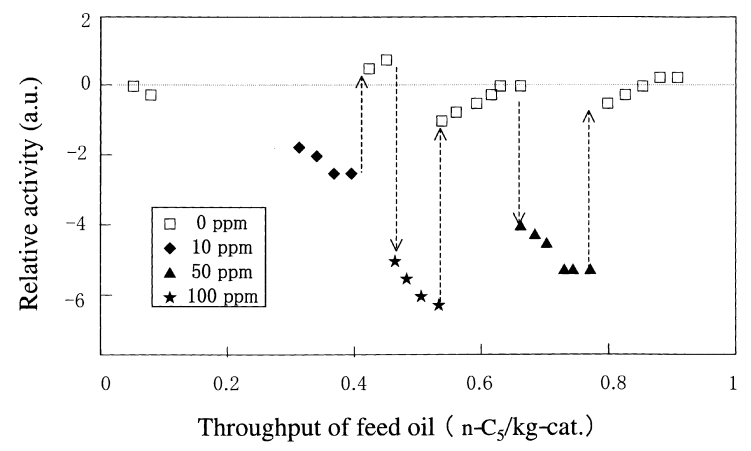

Feed oil: UFT-LN + DMDS. Temp. $=166^{\circ} \mathrm{C}$, Press. $=1.7 \mathrm{MPa}$, $\mathrm{WHSV}=1.6 \mathrm{~h}^{-1}, \mathrm{H}_{2} / \mathrm{HC}=2 \mathrm{~mol} / \mathrm{mol}$.

Fig. 14 Tolerance of $\mathrm{Pt} / \mathrm{SO}_{4}{ }^{2-} / \mathrm{ZrO}_{2}$ Catalyst to Sulfur in Feedstocks

\section{5. $\mathrm{Pt} / \mathrm{SO}_{4}{ }^{2-} / \mathrm{ZrO}_{2}$ 触媒を用いたライトナフサ異性化のエ 業化検討}

\subsection{1. 原料油中の水分の影響}

Fig. 13 に, $\mathrm{Pt} / \mathrm{SO}_{4}{ }^{2-} / \mathrm{ZrO}_{2}$ 触媒に打ける原料油中の水分量と して, 35 massppm までの影響結果を示す。この図から, 10 massppm では水分フリー原料油とほぼ同等で, 35 massppmの 原料油で若干の活性低下が見られた。しかし，実質的には問題 のない範囲と考えられ, $\mathrm{Pt} / \mathrm{SO}_{4}{ }^{2-} / \mathrm{ZrO}_{2}$ 触媒では飽和水分量（約 35 massppm）までは許容される。これは, ゼオライト系触媒 と同程度の性能であり, 塩素化アルミナ系触媒が 1 massppm 程度の水分の混入により大きな触媒劣化を示すのに比べると極 めて大きなメリットである。すなわち, 塩素化アルミナ触媒を 用いるプロセス ${ }^{50)}$ の場合に必須な原料油抢よびリサイクルガス のドライヤーを省略でき，プラント建設費のコストやプロセス 運転の簡略化につながることから工業的な意義が大きい。

\subsection{2 原料油中の硫黄分の影響}

$\mathrm{Pt} / \mathrm{SO}_{4}{ }^{2-} / \mathrm{ZrO}_{2}$ 触媒に扔ける原料油中の硫黄分の影響を Fig. 14 に示す。この図から, 硫黄分フリーの原料油から硫黄 分 10 massppm の原料系に替えると若干の活性低下があり，さ 
Table 5 Properties of Feedstock and Product in the Bench Plant Test

\begin{tabular}{lcc}
\hline & Feedstock & $\begin{array}{c}\text { Product oil } \\
(872-906 \mathrm{~h})\end{array}$ \\
\hline Sp. Gr. $\left(15 / 4^{\circ} \mathrm{C}\right)$ & 0.6512 & 0.6432 \\
\hline Composition [mass \%] & & \\
butane lighters & 2.5 & 7.7 \\
2,2-dimethylpropane & 0.1 & 0.1 \\
isopentane & 21.7 & 38.7 \\
pentane & 33.4 & 15.2 \\
2,2-dimethylbutane & 0.4 & 8.9 \\
cyclopentane & 0.2 & 1.2 \\
2,3-dimethylbutane & 1.6 & 3.6 \\
2-methylpentane & 11.8 & 11.2 \\
3-methylpentane & 7.1 & 6.8 \\
hexane & 14.3 & 5.1 \\
methylcyclopentane & 3.0 & 0.8 \\
benzene & 1.8 & $<0.1$ \\
cyclohexane & 0.1 & 0.4 \\
heptane heaviers & $<0.1$ & 0.6 \\
\hline \multicolumn{1}{c}{ RON } & 70.5 & 83.3 \\
\hline
\end{tabular}

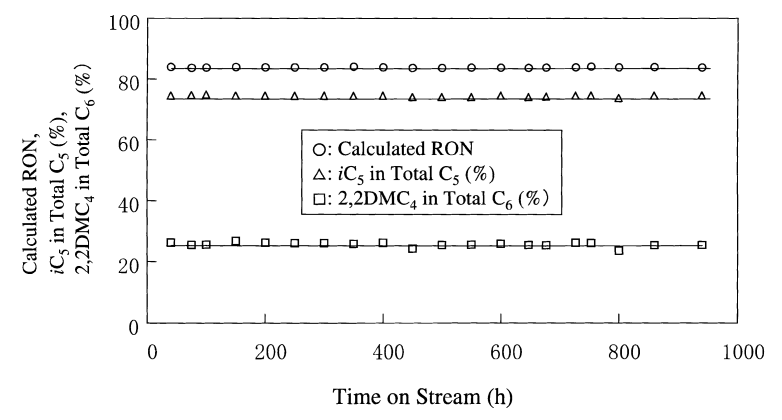

Catalyst: $\mathrm{Pt} / \mathrm{SO}_{4}{ }^{2-} / \mathrm{ZrO}_{2}$. Feed oil: UTL-LN. Temp. $=200^{\circ} \mathrm{C}$, Press. $=3 \mathrm{MPa}, \mathrm{LHSV}=6.7 \mathrm{~h}^{-1}, \mathrm{H}_{2} / \mathrm{oil}=270 \mathrm{~N} / / l$.

Fig. 15 Long Term Performance Test Results with $\mathrm{Pt} / \mathrm{SO}_{4}{ }^{2-} / \mathrm{ZrO}_{2}$ Catalyst

らに 50〜100 massppm の硫黄分を含む原料油では大幅な活性 低下が見られている。しかし，硫黄分を含む原料油で低下した 触媒活性は，その後の硫黄分フリー原料油の切り替えによりほ ぼ元の活性レベルに戻っていることから，硫黄分は $\mathrm{Pt} / \mathrm{SO}_{4}{ }^{2-}$ $\mathrm{ZrO}_{2}$ 触媒に対して可逆的な一時被毒である。

これらの結果から, $\mathrm{Pt} / \mathrm{SO}_{4}{ }^{2-} / \mathrm{ZrO}_{2}$ 触媒では原料油中の硫黄分 を 10 massppm 程度まで許容できると考えられ，これはゼオラ イト系触媒の許容量数十 massppm と同程度であり，また塩素 化アルミナ系触媒が原料の脱硫を 1 massppm 以下としなけれ ばならないことと比較すると優位性がある。

\subsection{3. 長期活性試験}

$\mathrm{Pt} / \mathrm{SO}_{4}{ }^{2-} / \mathrm{ZrO}_{2}$ 触媒の長期活性寿命について, 原料油および生 成油の組成, 性状を Table 5 に, ベンチプラントによる連続反 応実験結果を Fig. 15 にそれぞれ示す。反応実験は，硫黄分 1 massppm の脱硫ライトナフサを原料に反応温度 $200^{\circ} \mathrm{C}$, 反応圧 力 $3 \mathrm{MPa}$, LHSV $6.7 \mathrm{~h}^{-1}$ の一定の条件で行ったが，反応初期か ら $1000 \mathrm{~h}$ まで安定した反応活性を示している。また，約 $900 \mathrm{~h}$

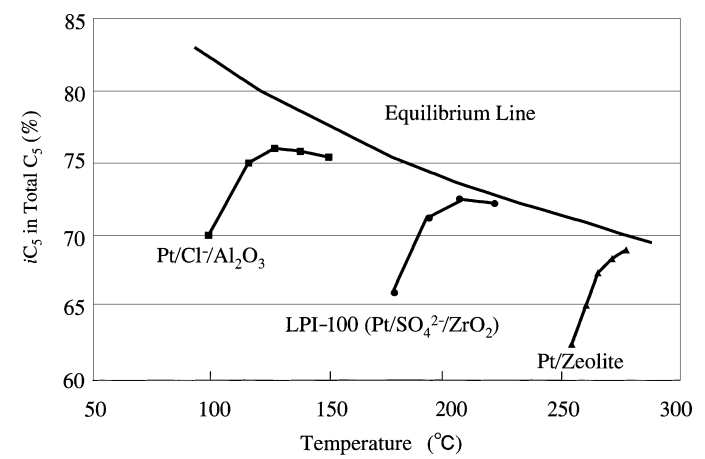

Fig. 16 Temperature Dependencies of $\mathrm{Pt} / \mathrm{SO}_{4}{ }^{2-} / \mathrm{ZrO}_{2}$ and Conventional Catalyst in Pentane Isomerization

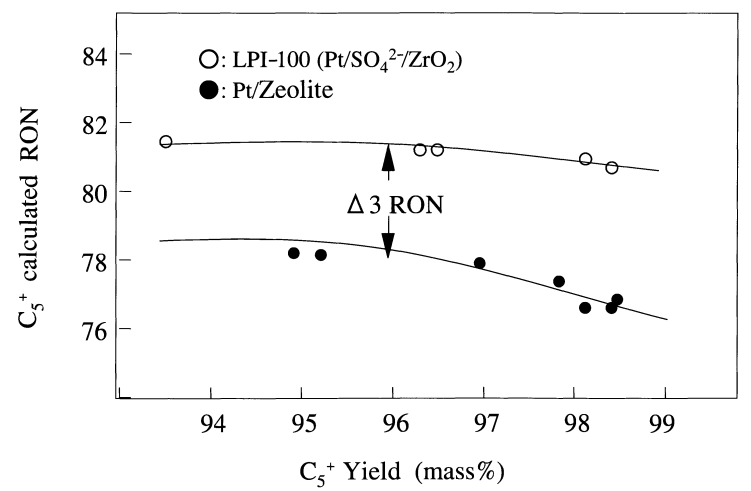

Fig. 17 Catalyst Comparison of RON vs. Liquid Yield in Pentane Isomerization ${ }^{9}$

後の生成油の分析結果から, リサーチ法オクタン価 (RON) が 70.5 の原料ライトナフサからは RON が 83.3 の生成油が得 られ，異性化反応により13 程度のオクタン価の向上が見られ た。

\section{6. 工業プロセスの概要と運転結果}

$\mathrm{Pt} / \mathrm{SO}_{4}{ }^{2-} / \mathrm{ZrO}_{2}$ 触媒を用いた新しいナフサ異性化工業プロセス は, コスモ石油(株)と三菱重工業(株)からライセンスを受けた UOP 社が 1995 年に工業的な触媒（LPI-100）とプロセス（Par$\mathrm{Isom}^{\mathrm{TM}}$ ) を完成させた。LPI-100 触媒の反応温度特性について は, Figs. 16 抢よび 17 に, Par-Isom ${ }^{\mathrm{TM}}$ プロセスについてはFig. 18 にそれぞれ示す。また, Table 6 に同プロセスの特徵を従来 の工業プロセスと比較して示すが，Pt / 塩素化アルミナ触媒 (低温型) と $\mathrm{Pt} /$ ゼオライト触媒 (高温型) の中間の反応温度 領域で最適活性が得られる。原料油中の水分, 硫黄分に対して は高温型触媒とほぼ同等であるが, 反応温度は $60 \sim 80^{\circ} \mathrm{C}$ 低く, さらに原料油も多く通油できることから経済性の高いプロセス である8)。設備的にはゼオライト系触媒を用いた既存の高温異 性化プロセスとほほ同様で, また未反応パラフィン成分のリサ イクルによりさらに高オクタン価が可能である。

Par-Isom ${ }^{\mathrm{TM}}$ プロセスの最初の商業運転は 1996 年 12 月に米国 の製油所で実施された8),9)。ここでは，これまで用いていたゼ オライト系触媒から LPI-100 触媒に入れ替えて運転を行ってお り, Tables 7, 8 にその時得られた両触媒間の性能比較結果を 
Table 6 Comparison between Par-Isom ${ }^{\mathrm{TM}}$ and Conventional Process for Naphtha Isomerization

\begin{tabular}{|c|c|c|c|c|}
\hline $\begin{array}{l}\text { Process } \\
\text { catalyst }\end{array}$ & & $\begin{array}{c}\text { Penex } \\
\mathrm{Pt} / \mathrm{Al}_{2} \mathrm{O}_{3}\end{array}$ & $\begin{array}{c}\text { Par-Isom }{ }^{\mathrm{TM}} \\
\mathrm{Pt} / \mathrm{SO}_{4}{ }^{2-} / \mathrm{ZrO}_{2}\end{array}$ & $\begin{array}{l}\text { Hysomer } \\
\text { Pt/Zeolite }\end{array}$ \\
\hline \multicolumn{5}{|c|}{ Feed oil limitations } \\
\hline Sulfur & [mass ppm] & $<0.1$ & $<20$ & $<20$ \\
\hline Water & [mass ppm] & $<0.1$ & $<30$ & $<30$ \\
\hline Aromatics & [mass \%] & $<2$ & $<2$ & $<2$ \\
\hline $\mathrm{C}_{7}^{+}$ & [mass \%] & $<2$ & $<2$ & $<2$ \\
\hline \multicolumn{5}{|c|}{ Reaction condition } \\
\hline Temperature & {$\left[{ }^{\circ} \mathrm{C}\right]$} & $120-160$ & $180-240$ & $220-300$ \\
\hline Pressure & {$[\mathrm{MPa}]$} & 3 & 3 & 3 \\
\hline LHSV & {$\left[\mathrm{h}^{-1}\right]$} & $1-2$ & 3.0 & $2-3$ \\
\hline \multicolumn{5}{|c|}{ Product oil (isomerate) } \\
\hline Yield & [mass \%] & 99.0 & 98.5 & 98.0 \\
\hline RON & & 83 & 81 & 77 \\
\hline
\end{tabular}

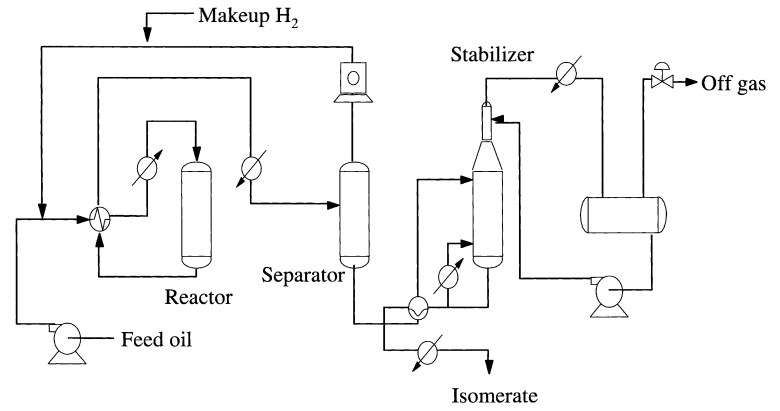

Fig. 18 Par-Isom ${ }^{\mathrm{TM}}$ Process Flow
Table 7 Commercial Performance of LPI-100 Catalyst Compared with Zeolite Type Catalyst

\begin{tabular}{|c|c|c|c|}
\hline \multicolumn{2}{|l|}{ Catalyst } & $\begin{array}{c}\text { LPI-100 } \\
\left(\mathrm{Pt} / \mathrm{SO}_{4}{ }^{2-} / \mathrm{ZrO}_{2}\right)\end{array}$ & Zeolite type \\
\hline Temp. & {$\left[{ }^{\circ} \mathrm{C}\right]$} & 188 & $254-299$ \\
\hline$\Delta T$ & {$\left[{ }^{\circ} \mathrm{C}\right]$} & 42 & $39-44$ \\
\hline Pressure & {$[\mathrm{MPa}]$} & 2.78 & 2.43 \\
\hline WHSV & {$\left[\mathrm{h}^{-1}\right]$} & 1.5 & 1.5 \\
\hline Feed rate & [BPD] & $800-1200$ & $800-1200$ \\
\hline $\mathrm{H}_{2} / \mathrm{HC}$ & {$[\mathrm{mol} / \mathrm{mol}]$} & 2.0 & 2.0 \\
\hline \multicolumn{2}{|c|}{ Conv. $\left(i-\mathrm{C}_{5} \%\right)$} & $72-73$ & $58-60$ \\
\hline \multicolumn{2}{|c|}{$\left(2,2-\mathrm{DMC}_{4} \%\right)$} & $24-25$ & $15-16$ \\
\hline Liquid yield & [vol\%] & 98 & 97 \\
\hline RON & & 81 & 78 \\
\hline
\end{tabular}

Table 8 Performance of LPI-100 Catalyst Revamp ${ }^{20)}$

\begin{tabular}{lcccc}
\hline Catalyst & Zeolite & $\begin{array}{c}\text { LPI-100 } \\
\left(\mathrm{Pt} / \mathrm{SO}_{4}^{2-} / \mathrm{ZrO}_{2}\right)\end{array}$ & Improvement ${ }^{\mathrm{a})}$ \\
\hline Capacity & {$[\mathrm{BPD} \%]$} & 825 & 900 & +9.3 \\
Product $\mathrm{C}_{5}{ }^{+} \mathrm{RON}$ & & 76.9 & 96.5 & +2.4 \\
Yield & {$[$ mass \%] } & 91.7 & 96.8 \\
\hline
\end{tabular}

a) Compared with zeolite type catalyst.

示す。LPI-100 触媒では，これまでのゼオライト系触媒よりも 反応温度が大幅に低下し, 同一チャージ量, 同一 WHSV とい う条件で得られた生成油は RON が 81 とゼオライト系触媒よ りも RONが3 増加し, ベンチプラント試験で得られた結果と 同等の性能を示した。

\section{4. おわりに}

本報で紹介した $\mathrm{Pt} / \mathrm{SO}_{4}{ }^{2-} / \mathrm{ZrO}_{2}$ 触媒は，それまで知られてい た硫酸処理ジルコニア系触媒が固体酸触媒として目新しいもの の，その寿命に問題があることから実験室での研究対象でしか なかったのに対し，工業的に利用可能な新規の固体酸触媒とし て評価が急速に高まった。この結果，これに類似した組成の触 媒を対象にした研究が数多く報告されようになり，現在では触 媒研究の一大分野になりつつある。この中には, 硫酸根処理ジ
ルコニアに $\mathrm{Fe}$ と $\mathrm{Mn}$ を少量担持した触媒や硫酸根の代わりに $\mathrm{WO}_{3}$ を用いた $\mathrm{WO}_{3} / \mathrm{ZrO}_{2}$ 触媒等, $\mathrm{Pt} / \mathrm{SO}_{4}{ }^{2-} / \mathrm{ZrO}_{2}$ 触媒とは特性の 異なる固体超強酸性も報告されており今後の展開が期待され る。なお，本文では紹介できなかった $\mathrm{SO}_{4}{ }^{2-} / \mathrm{ZrO}_{2}$ 触媒系に関す る詳細については総合論文 57) 66) を参照願いたい。

最後に, 本開発技術は研究開始から実用化に至るまで 10 年 以上に渡り, 多くの関係者や諸先輩の熱意と努力によって達成 されたことを記して謝辞といたします。

\section{References}

1) Holm, V. C. F., Bailey, G. C., U. S. Pat. 3032599 (1962).

2) Hino, M., Arata, K., J. Chem. Soc., Chem. Commun., 1148 (1979).

3) Hino, M., Kobayashi, S., Arata, K., J. Am. Chem. Soc., 101, 6439 (1979). 
4) Baba, S., Shibata, Y., Kawamura, T., Takaoka, H., Kimura T., Kousaka, K., Minato, Y., Yokoyama, N., Iida, K., Imai, T., Jpn. Kokoku Tokkyo Koho JP05-29503 (1993), JP0529504 (1993), JP05-29505 (1993), JP05-29506 (1993), JP0581304 (1993).

5) Hosoi, T., Shimizu, T., Itoh, S., Baba, S., Takaoka, H., Imai, T., Yokoyama, N., Prep. Am. Chem. Soc., Div. Petrol. Chem., 33, 562 (1988).

6) Hosoi, T., Kitada, S., Shimizu, T., Imai, T., Nojima, S., Shokubai, 32, 117 (1990).

7) Shimizu, T., Kitada, S., Hosoi, T., Imai, T., Nojima, S., Proceed. 4th Japan-China-U.S.A. Sympo. Catal., (1989), p. 326

8) Gosling, C. D., Rosin, R. R., Bullen, P., Shimizu, T., Imai, T., Petrol. Tech. Quart., Winter, 55 (1997/1998).

9) Cleveland, M. J., Gosling, C. D., Utley, J., Elstein, J., NPRA Annual Meeting, AM-99-29.

10) Kimura, T., PETROTECH, 25, (2), 111 (2002).

11) Kimura, T., Catal. Today, 81, 57 (2003).

12) Voorhies, A., Jr., Bryant, P. A., AIChE. J., 14, (6), 853 (1968).

13) Hino, M., Arata, K., Hyoumen, 28, 481 (1990).

14) Comelli, R. A., Vera, C. R., Parera, J. M., J. Catal., 151, 96 (1995).

15) Hino, M., Arata, K., Catal. Lett., 30, 25 (1995).

16) Hino, M., Arata, K., Hyoumen, 34, 50 (1996).

17) Comelli, R. A., Canavese, S. A., Vandagna, S. R., Figoli, N. S., Appl. Catal. A: General, 135, 287 (1996).

18) Milburn, D. R., Keogh, R. A., Davis, B. H., Prep. Am. Chem. Soc., Div. Petrol. Chem., 42, 754 (1997).

19) Hua, W., Smmer, J., Appl. Catal. A: General, 227, 279 (2002).

20) Yori, J. C., Parera, J. M., Appl. Catal. A: General, 129, 83 (1995).

21) Arata, K., Hino, M., Hyoumen, 19, 75 (1981).

22) Bolis, V., Magnacca, G., Cerrato, G., Morterra, C., Langmuir, 13, 888 (1997).

23) Zhang, C., Miranda, R., Davis, B. H., Catal. Lett., 29, 349 (1994).

24) Vandagna, S. R., Comelli, R. A., Figoli, N. S., React. Kinet. Catal. Lett., 63, 33 (1998).

25) Ebitani, K., Konishi, J., Hattori, H., J. Catal., 130, 257 (1991).

26) Ebitani, K., Konno, H., Tanaka, T., Hattori, H., J. Catal., 135, 60 (1992).

27) Ebitani, K., Tsuji, J., Hattori, H., Kita, H., J. Catal., 135, 609 (1992).

28) Hattori, H., Stud. Surf. Sci. Catal., 77, 69 (1993).

29) Ebitani, K., Tanaka, T., Hattori, H., Appl. Catal. A: General, 102, 79 (1993).

30) Hattori, H., Ebitani, K., Hyoumen, 32, 32 (1994).

31) Hattori, H., Shishido, T., Tsuji, J., Nagase, T., Kita, H., Stud. Surf. Sci. Catal., 92, 93 (1995).

32) Tanaka, T., Shishido, T., Hattori, H., Ebitani, K., Yoshida, S., Physica B, 208 \& 209, 649 (1995).

33) Shishido, T., Tanaka, T., Hattori, H., J. Catal., 172, 24 (1997).
34) Hattori, H., Yamada, T., Shishido, T., Res. Chem. Intermed., 24, (4), 439 (1998).

35) Signoretto, M., Pinna, F., Strukul, G., Cerrato, G., Morterra, C., Catal. Lett., 36, 129 (1996).

36) Vaudagna, S. R., Comelli, R. A., Figoli, N. S., React. Kinet. Catal. Lett., 63, 33 (1998).

37) Manoli, J. M., Potvin, C., Muhler, M., Resofszki, G., Buchholz, T., Paal, Z., J. Catal., 178, 338 (1998).

38) Sayari, A., Dicko, A., J. Catal., 145, 561 (1994).

39) Dicko, A., Song, X., Adnot, A., Sayari, A., J. Catal., 150, 254 (1994).

40) Zhao, J., Huffman, G. P., Davis, B. H., Catal. Lett., 24, 385, (1994).

41) Srinivasan, R., Sparks, D. E., Davis, B. H., Catal. Lett., 40, 167, (1996).

42) Paal, Z., Muhler, M., Schlogl, R., J. Catal., 143, 318 (1993).

43) Xu, B. Q., Sachtler, W. M. H., J. Catal., 167, 224 (1997).

44) Van Mao, L., Xiao, S., Si Le, T., Catal. Lett., 32, 256 (1995).

45) Hattori, H., PETROTECH, 25, (2), 106 (2002).

46) Iglesia, E., Soled, S. L., Kramer, M., J. Catal., 144, 238 (1993).

47) Ono, Y., PETROTECH, 25, (2), 92 (2002).

48) Sommer, J., Jost, R., Hachoumy, M., Catal. Today, 38, 309 (1997).

49) Okuhara, T., Echizen, T., PETROTECH, 25, (2), 98 (2002).

50) Cusher, N. A., "Handbook of Petroleum Refining Process," ed. by Meyers, R. A., McGraw Hill, New York (1996), p. 9.15-9.27.

51) Kouwenhoven, H. W., Langhout, W. C., Van, Z., Chem. Eng. Progr., 67, 65 (1971).

52) Chao, K., Wu, H. C., Leu., L. J., J. Catal., 157, 289 (1995)

53) Shishido, T., Hattori, H., J. Catal., 161, 194 (1996).

54) Tran, M. T., Gnep, N. S., Guisnet, M., Nascimento, P., Catal. Lett., 47, 57 (1997).

55) Comelli, R. A., Sergio, F., Vandagna, R., Figoli, S., Catal. Lett., 45, 227 (1997).

56) Duchet, D. G., Monnier, A., Dujardin, C., Gilson, J. P., Gestel, J. V., Szabo, G., Nascimento, P., J. Catal., 198, 328 (2001).

57) Hattori, H., Shokubai, 45, 327 (2003).

58) Arata, K., "Advances in Catalysis," eds. by Eley, D. D., Pines, H., Weisz, P. B., Vol. 37, Academic Press, New York (1990), p. 165-211.

59) Yamaguchi, T., Appl. Catal., 61, 1 (1990).

60) Iglesia, E., Soled, S. L., Kramer, G. M., J. Catal., 144, 238 (1993).

61) Davis, B. H., Keogh, R. A., Srinivasan, R., Catal. Today, 20, 219 (1994)

62) Song, X., Sayari, A., Appl. Catal. A: General, 110, 121 (1994).

63) Cormara, A., Chem. Rev., 95, 559 (1995).

64) Arata, K., Sekiyu Gakkaishi (J. Jpn. Petrol. Inst.), 39, (3), 185 (1996).

65) Arata, K., PETROTECH, 19, (9), 733 (1996)

66) Okuhara, T., Sekiyu Gakkaishi (J. Jpn. Petrol. Inst.), 47, (1), 1 (2004). 
要旨

\title{
白金-硫酸根ジルコニア触媒によるライトナフサの異性化
}

\author{
木村 孝夫 $^{\dagger 1), \dagger 3)}$, 清水 俊夫 $^{\dagger 1)}$, 今井 哲也 ${ }^{\dagger 2}$ \\ †1) コスモ石油(株) 中央研究所, 340-0193 埼玉県幸手市権現堂 1134-2 \\ †2) 三菱重工業(株)技術本部広島研究所，733-8553 広島市西区観音新町 4 丁目 6 番 22 号 \\ †3) (現在) コスモ石油(株)海外技術協力センター，180-8564 東京都港区芝浦 4-9-25 芝浦スクエアビル
}

ペンタン異性化反応に拈いて, 硫酸根処理ジルコニア $\left(\mathrm{SO}_{4}{ }^{2-} / \mathrm{ZrO}_{2}\right)$ 触媒は高い異性化能を持つものの短時間に劣化 する。本研究では異性化活性の安定化を目的に, 白金を担持し た $\mathrm{Pt} / \mathrm{SO}_{4}{ }^{2-} / \mathrm{ZrO}_{2}$ 触媒を調製し, 硫酸根処理条件，白金の役割 および反応機構等について考察した。その結果, 少量の白金担 持により触媒上のコーク生成が大幅に低減し, ペンタン異性化 反応においても極めて安定な触媒活性を示した。また, 異性化 活性は焼成温度および硫酸根処理剤に依存した。このPtの役 割は，触媒酸点上で生成したコーク前駆体を水素化により脱離
促進しているほか，オレフィンを経由する二元機能反応におけ る脱水素抢よび水素化反応に寄与しているものと考察した。

$\mathrm{Pt} / \mathrm{SO}_{4}{ }^{2-} / \mathrm{ZrO}_{2}$ 触媒は, ライトナフサ異性化に扔いて従来工業 的に用いられていたゼオライト系触媒よりも高い低温活性を示 し, 塩素化アルミナ系触媒と比較して原料油の水分㧍よび硫黄 分への耐性が優れていることが分かった。また，本開発触媒を 用いた商業運転では, これまでのゼオライト系触媒よりも反応 温度が大幅に低下し, 生成油のリサーチ法オクタン価（RON） は 81 と 3 ポイント増加する良好な結果が得られた。 